\title{
Tourism as a Factor of Demand in Public Road Passenger Transportation in the Republic of Croatia
}

\author{
Goran Kos, Neven Ivandić, Krešimir Vidović
}

\begin{abstract}
The paper presents the results of research in tourism as one of the most important factors in the public passenger transport demand. The research has been carried out for the requirements of creating a Tourism Satellite Account (TSA) for the Republic of Croatia for 2016. Traffic and tourism, as strategic economic activities of the Republic of Croatia, have the characteristics of complex and dynamic systems, mutually conditioned by the guidelines of the demand and supply chain of tourist product values. Therefore, the paper is oriented towards the analysis of the significance of tourism for public road passenger transport in the Republic of Croatia. During 2016, road intercity passenger transport carried 50.4 million passengers, out of which 98 percent in domestic and 2 percent in international transport. Passenger road transportation is marked by mild seasonal oscillations, with the summer period marked by the lowest level of demand, and the period from January to March by the largest number of passengers. The provision of public road transportation services in 2016 realised a revenue of 1.8 billion kuna for 433 business subjects registered in this activity. The trends indicate an increase in the number of travelled kilometres by buses with passengers.
\end{abstract}

Keywords: public bus transport; tourism; tourism satellite account; tourism transport demand

\section{INTRODUCTION}

Tourism is one of the most significant factors of demand in the public road passenger transportation. In order to determine the share of public road passenger transportation that participates in generating the revenues, the paper presents the results of studies carried out for the requirements of the Tourism Satellite Account (TSA) of the Republic of Croatia for 2016. The Tourism Satellite Account provides an insight into the macro-economic aggregates that describe the volume and the economic impact of tourism based on observing the expenditures of visitors according to their origin and the integration of the expenditures of visitors with the tables of supply and use of national accounts.

The aim of the paper is to analyse the volume and characteristics of tourism demand in public road passenger transportation in the Republic of Croatia in order to comprehend the significance of tourism for this economic activity, but also to determine the key physical and monetary features of the total demand and the demand of visitors.

The first Section contains introductory observations. The second Section provides an overview of key literature that connects the research in the domain of tourism and public road passenger transportation. The key papers published over the last thirty years have been analysed. The third Section provides insight into the methodology of using the Tourism Satellite Account as a means of measuring the significance of tourism for the public road passenger transportation. The Tourism Satellite Account is a methodology founded by the United Nations World Tourism Organisation (UNWTO), which uses the concepts, classifications, definitions, tables and aggregates to measure the economic effects of tourism on a national economy at an annual basis. The fourth Section contains the analysis and key characteristics of public road passenger transportation and tourism in Croatia, whereas the fifth Section presents the results of studying the characteristics of passengers and tourists in Croatia. The sixth Section contains the concluding observations and proposals for future research.

\section{LITERATURE REVIEW}

The studies that connect tourism and transportation started in the mid-1980s [1,2]. Such studies usually referred to the transportation of tourists by air, rail and water transport (sea and river transportation of tourists). The studies related to the road transport of tourists were mostly reduced to the study of tourists travelling by passenger cars, i.e. individual road transportation means. There are few studies carried out that indicate the use of public road passenger transportation of tourists in tourism destinations, i.e. tourism attractive areas.

More recent studies, i.e. the ones dating to the beginning of this century, began with the authors Van Middelkoop et al. who collected data about the selection of tourism destinations in order to define the rules for developing trip models. The data were collected and analysed in the Netherlands in 1998 [3].

The studies that followed and were carried out by the author Awaritefe considered mainly the motives of tourists in the selection of tourism destinations. Studies were also carried out in Third World countries [4]. The attractiveness of the destination, high-quality services, facilities, a favourable location and accessibility of destinations are the most important factors in the selection of a tourism destination. Public transportation also proved to be an important factor in the selection of the destination, i.e. tourists were more motivated to visit a destination that provided a better public transportation connection.

In the paper [5], the authors Jurčević et al. studied the relation between tourism and the transportation industry in the Republic of Croatia, whose share of tourism amounts to almost one fifth of the GDP. The most important thing from the transportation aspect is certainly the infrastructure of all transport branches, but primarily of road transport. 
At the same time, there are problems in the destinations that attract an excessive number of tourists, i.e. areas where the limits of the carrying capacity of tourists are exceeded. The authors Aguilo et al. [6] studied different strategies in the tourism policy intended to reduce the number of tourists who use private transportation by motor vehicles and represent the need for a greater usage of public, group or charter transportation in the destinations. Taking the Balearic Islands as the case study, discrete models of selection were used to evaluate various methods of modelling the function of transportation demand for the lease of cars and public buses, and in this way they identify the corrective potential of the proposed policy.

For the needs of modelling traffic during the tourist season, there is an increasing need for new traffic models that would be implemented during and outside the tourist season. Paper [7] by Novačko et al. presents a model for the evaluation of data for the need of a classical four-stage model of transportation demand by passenger cars in small towns and a suitable model for tourism destinations. The procedure consists of creating an initial origin-destination travel matrix from the data on the traffic count and the definition of an average rate of generating the travelling of households and tourists.

The authors Ševrović et al. [8] studied the public transport of passengers and the model of the distribution of transportation costs in the public urban and suburban transport. The paper gives an overview of the level of subsidising the public transportation of passengers in European cities and cities in the Republic of Croatia. Based on the example of passenger transportation in the DubrovnikNeretva County, the region in the south part of Mediterranean Croatia, a general proposal of the model of expenditure distribution has been presented, and an example of cost distribution per units of local self-government has been given. The research was carried out in a distinctly tourist region with a high seasonality feature in the number of tourists during the year.

The relation of tourism demand in public passenger transportation is also in the focus of the International Association of Public Transport (UITP). Their studies show that public transportation contributes to the global attractiveness of the city - destination [9]. This plays an important role in the development of urban tourism, since public transportation is often the main transportation means for visitors - either for travelling to work, getting to know the city, arriving to visit the cultural sights. The studies of the US association of public carriers have shown that cities which offer bus and rail transport to airports are more attractive for business passengers, international conferences and meetings, thus realizing the benefits to the local economy. In the association, they state that public transportation generates a wide spectrum of economic benefits for cities. Public transportation in cities allows savings and creates value for individuals, companies and the public authority, especially through higher tax revenues. Public transportation also helps in influencing private investments in the city centres. Overall, an investment into public transportation generates value which exceeds the initial investment by three to four times.
When public transportation systems are integrated into the strategies of economic development - urban development and housing policies, education and employment strategies, as well as the tourism sector-cities can truly evolve.

The service of transportation in tourism depends on the physical availability of the destination, movement within the destination and the transport itself [10]; as it is stated in the research by the authors Kovačić et al. In today's world, transportation is not just an attraction of a desired destination. The authors state that travelling by a certain vehicle can be a tourist attraction if the transportation means has been designed to evoke a sense of joy and excitement. The authors analyse transport modes that are an attraction and provide an overview of certain modes of transportation. It is also stated that the foreign tourists arriving to Croatia mostly arrive by cars and other road vehicles (91 percent), whereas other modes of transportation are less represented (air transport eight percent, shipping - one percent, rail transport represented only marginally) [11].

In the paper [12], authors Purba et al. conclude that the quality of service is the key indicator of the system, since many elements that represent the quality of service are in the transport system. The goal of the mentioned research has been to define the main aspects of the quality of service of the transit system in a tourist-educational city and a business city.

The authors Hall et al. [13] carried out a research on the use of public transportation by the tourists (their choice, problems, desires and habits) and how to direct the tourists to more sustainable methods of travelling than that of individual transport. The authors focused on marketing and its role in the promotion of travelling. Different factors that affect travelling include habits, such as gender, age, socioeconomic status, culture and language. The authors recommend more information on the availability of material in English, signs and maps that are easy to understand. One of the main conclusions drawn by the authors is that "customers want a transportation system that satisfies their needs." In another paper by the same authors [14], they claim that "poor public transport may be detrimental to the tourism experience, but top public transport will not necessarily improve it."

The authors Babić et al. [15] analyse the quality of services provided by bus terminals and conclude that good functioning of the terminal is the key factor for the tourism promotion of single tourism regions, starting from the assumption that guests form their first impression when arriving to the bus terminal. The research referred to the satisfaction evaluation of the customers in terms of the quality of certain services of the main bus terminal of the city of Rijeka in Croatia. By analysing the collected surveys, it has been determined that the level of dissatisfaction was the highest in relation to the layout of the waiting room, functionality of platforms and the quality of the facilities and services, which confirms the need for infrastructure modernisation.

Authors Castillo-Manzanoa et al. [16] have stated that tourism plays an important role in the economic growth, particularly in middle- and high-income countries, with a 
strong correlation to the transport sector. They determined that the provision of adequate transport means is a key requirement for the development of any tourism destination, especially for air transport and high-speed rail. The analysis covers 28 EU countries for the period from 1996 to 2014.

Extensive research in the area of using public transport for the transport of tourists was carried out by Gronau [17]. The ever-growing transport demand by tourists in holiday destinations and an increase of $\mathrm{CO}_{2}$ emissions motivates a new trend among the German destinations - promotion of green transport for the tourists. A key innovation is the guest ticket concept, which offers tourists with the option of free public transport, for buses and trains, within the defined destination areas during their stay. Research shows that tourist companies and local politicians do not see the need for sustainable transportation, nor the need for behavioural change among tourists. Larger travel agencies were more inclined to support guest tickets. A project which brings together 25 local tourist boards in six Alpine countries to support and promote soft mobility has been described. Most municipalities are in Austria and Italy.

Authors Gross et al. [18] studied the guidelines that affect the selection of the tourist transportation choice, i.e. a contribution to sustainable tourist accommodation. The analysis shows that the most important socio-demographic guidelines of using public transport are age, household size, household net income, availability of cars and current professional activity.

Authors Le-Klähn et al. [19] considered how the models of tourist movements and transport modes are important topics in tourism research. However, little is known about how tourists in urban destinations make decisions on which areas to visit and how to use transportation to the place of attraction. Research results show that the choice of tourists in terms of the transport mode and the visited areas is closely connected and should therefore be jointly considered. Public transport in urban destinations is likely to be used by wellinformed visitors, who are also aware of the cost of transport.

The travel partner and motivation also affect the choice of the method of operation. The decision about travelling outside the city is influenced by the country of residence of the visitor, length of stay, number of previous trips, perception of ease of travel, and local attractions. The research confirmed that public transport is a dominant method of transportation for the tourists who visit smaller areas (i.e. stay in the city), while other modes of transport are used for out-of-town travel. They also studied the influence of introducing special tourist tickets for people who travel in a group of maximum five people, an attractive marketing strategy that should be adopted by other cities. Since the price is an important factor in the selection of the operation mode, tourists are offered discounts and promotions are organised.

The mode of transport and the spatial scope of the visits are interconnected. Therefore, in order to ensure sustainable mobility with the support to the dispersion of tourists, provision of efficient and well-connected systems of public transport is of utmost importance for the cities. This is particularly important for the improvement of destination attraction since transportation is part of the tourist experience and satisfaction with the destination. Tourists are more motivated to visit destinations with good public transport and vice versa, whereas destinations with poor public transport are less attractive to tourists.

\section{TOURISM SATELLITE ACCOUNT AS A MEANS OF MEASURING THE IMPORTANCE OF TOURISM FOR PUBLIC ROAD PASSENGER TRANSPORTATION}

The specific characteristics of tourism originate from the fact that tourism determines the position of a customer, and not the kinds of produced assets or services, the type of used or spent inputs, the use of production inputs or production method. As a phenomenon related to the travelling of people, from the aspect of demand, tourism includes activities of visitors and their roles in the purchase of goods and services, whereas from the aspect of supply, tourism needs to be understood as a set of production activities which are mainly oriented to the demand generated by visitors, i.e. as an amalgam of industries such as transport, accommodation, serving of food and drinks, recreation and entertainment, as well as travel agencies [20].

Such understanding of tourism has also resulted in the establishment of the methodological frames for the Tourism Satellite Account as a system which, by representing a link between tourist statistics (International Recommendations on Tourism Statistics - IRTS 2008) [21] and standard tables of national accounts (Fig. 1), enables the measurement of the economic influence of the direct contact of visitors and suppliers/producers of the products and services required by visitors; in other words, the direct influence of tourism on the economy.
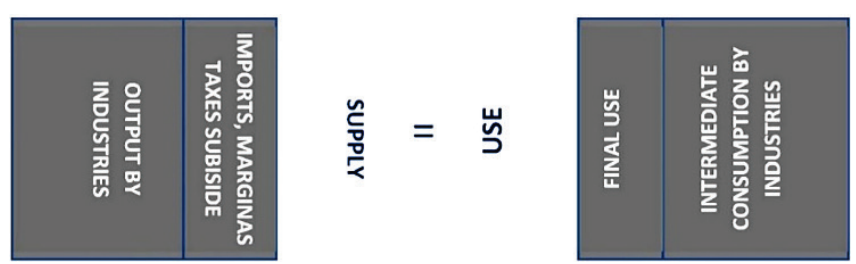

Figure 1 Graphical representation of the supply and use tables balance

Source: authors on the basis Statistical Division, Unated Nations (2018)

Representing a step forward in quantifying and harmonizing the direct effects of tourism based on a clearly understandable, equivalent, and internationally binding accountancy system, the Tourism Satellite Account represents a system of concepts, classifications, definitions, tables (Fig. 2) and aggregates connected from the functional perspective with the standard tables of the System of National Accounts. During 2008, the second version of the conceptual frame established in 2000 and titled 2008 Tourism Satellite Account: Recommended Methodological Framework (TSA: RMF 2008) [22] was launched in order to "ensure better internal consistency of tourism statistics with the rest of the statistical system of the country and to ensure better international comparability of data." [20]. Following concepts and definitions are key for compilation of the Tourism Satellite Account (according to TSA: RMF 2008 and IRTS 2008 [21, 22]): 
- tourism - includes the activities of persons who travel and stay in places outside their usual environment, not longer than one year in continuation, for holidays, business and other reasons, if the activities in this case are not being paid from the very place of visit (payments that cover the remuneration). The basic forms of tourism are:

- domestic tourism - activities of persons with permanent residence in the given area, who travel within this area, as well as outside their usual environment;

- incoming tourism - activities of persons who have no permanent residence in the given area, and who travel through the area that is outside their usual environment, and

- outgoing tourism - activities of persons with permanent residence in the given area, who travel and stay in places outside that area.

According to the country of origin, the categories of tourism are:

- interior tourism - domestic tourism and incoming tourism,

- national tourism - domestic tourism and incoming tourism, and

- international tourism - arrival tourism and outgoing tourism.

- visitor - as a narrower concept than a passenger, a visitor is any person who travels to a place different from their usual environment for a period shorter than 12 months, whose main travelling purpose is not the performance of an activity funded by the visited place. The visitors can be:

- tourists - visitors who stay for at least one night in a commercial or non-commercial accommodation in the visited place / country, and

- one-day visitors - visitors who do not spend a night in a commercial or non-commercial accommodation in the visited place / country.

- usual environment - represents a complex concept which differs from country to country reflecting a different density of the population, cultural habits, availability of transport, vicinity of national and administrative borders. Regardless of these differences, the concept of the usual environment can be related to the following criteria:

- frequency of travelling (except for visits to holiday houses that always represent tourism travelling),
- duration of travelling,

- crossing of administrative and national borders, and

- distance from the place of usual residence (it is recommended that the distance from the place of residence is used as an additional criterion, with the frequency and duration of travel and the crossing of administrative borders).

An important feature of tourism characteristic activities is that they must serve directly the visitors, which means that these are the activities in which there are direct contacts between product / service providers and customers. This requirement does not represent a limitation since in the catering activities, the producer and the salesperson are usually the same subject, whereas in the case of a product, there is usually one or several intermediaries between the goods producer and the end-customer.

Table 1 Tourist characteristic products for the consumption and tourism characteristic activities (tourism activities). Source: TSA: RMF 2008 [20]

\begin{tabular}{|l|l|}
\hline \multicolumn{1}{|c|}{ Products } & \multicolumn{1}{c|}{ Tourism activities } \\
\hline $\begin{array}{l}\text { 1. accommodation services for } \\
\text { visitors }\end{array}$ & 1. accommodation for visitors \\
\hline $\begin{array}{l}\text { 2. services of food and drinks } \\
\text { catering }\end{array}$ & $\begin{array}{l}\text { 2. activity of serving food and } \\
\text { drinks }\end{array}$ \\
\hline 3. inter-city rail passenger services & 3. rail passenger transport \\
\hline $\begin{array}{l}\text { 4. road passenger transport } \\
\text { services }\end{array}$ & 4. road passenger transport \\
\hline $\begin{array}{l}\text { 5. water passenger transport } \\
\text { services }\end{array}$ & 5. water passenger transport \\
\hline 6. air passenger transport services & 6. air passenger transport \\
\hline $\begin{array}{l}\text { 7. renting of equipment for } \\
\text { passenger transportation }\end{array}$ & $\begin{array}{l}\text { 7. renting of equipment for } \\
\text { passenger transport }\end{array}$ \\
\hline $\begin{array}{l}\text { 8. services of travel agencies and } \\
\text { other booking services }\end{array}$ & $\begin{array}{l}\text { 8. travel agencies and other } \\
\text { activities of providing booking } \\
\text { services }\end{array}$ \\
\hline 9. cultural services & 9. culture \\
\hline 10. sport and recreation services & 10. sport and recreation \\
\hline $\begin{array}{l}\text { 11. products characteristic for } \\
\text { tourism in a specific country }\end{array}$ & $\begin{array}{l}\text { 11. retail with products } \\
\text { characteristic for tourism in a } \\
\text { specific country }\end{array}$ \\
\hline $\begin{array}{l}\text { 12. services characteristic for } \\
\text { tourism in a specific country }\end{array}$ & $\begin{array}{l}\text { 12. other activities characteristic } \\
\text { for tourism in a specific country }\end{array}$ \\
\hline
\end{tabular}

Tourist activity represents a set of statistical units/plants that for their main activity (activity that generates the highest added value) have the activity characteristic for tourism (Tab. $1)$.
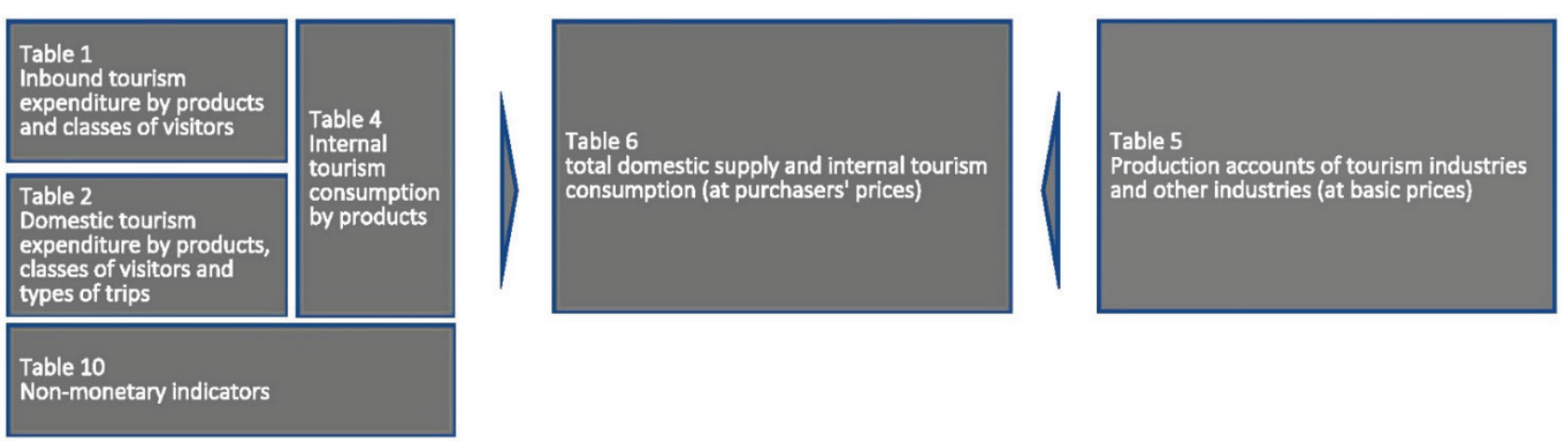

Figure 2 Graphical representation of tourism satellite account core tables Source: authors on the basis of 2018 RMF: RMF 
The term statistical unit/plant can be described as a company, or its part, that participates in one, or prevailingly one, type of economic activity from one location or one geographic area, for which the data are available. Since business subjects can also have a secondary activity, tourist activities can also produce products that are not products characteristic for tourism.

The determination of tourist activities in TSA: RMF 2008 has been adapted to the ISIC classification (International Standard Industrial Classification of All Economic Activities, ISIC, Rev. 4), with separation of the socalled tourism activities characteristic for tourism and activities that are characteristic for tourism of a certain country.

Access to the assessment of the volume of road passenger transport services in the tourism satellite account $[22,23]$ is related to the treatment of the key modes of the used transport (rail, road, air and sea) and the status of tourists (domestic, outgoing, incoming).

The definition of a visitor does not include only the individual passengers who travel for personal reasons, but also the passengers who travel for business. The consumption by business passengers can be wholly or partly paid by the employer (covering of accommodation costs, etc.) which in the frame of the European System of National and Regional accounts [24], understands that these expenditures are observed as the intermediary consumption of the production unit regardless of the method in which these services are purchased. However, as part of tourism statistics, these expenditures are regarded as tourism consumption since they are directly connected with the activities of the visitors on their trip.

Such approach limits the possibility of comparing tourism consumption with the aggregate final consumption of the households since tourism consumption does not have to be part of the final consumption.

The classification of products related to passenger transport has been defined in the frame of the International Recommendations for Tourism Statistics 2008 [21]. This document, namely, contains the identification of products (products characteristic for tourism, related products and other products for consumption) and tourism industries in compliance with the internationally adopted classification of products and production activities (Central Product Classification - CPC, Ver. 2 and International Standard Industrial Classification of All Economic Activities - ISIC, Rev. 4).

The group of products characteristics for tourism also includes the products of passenger transport, these being the services of rail, road, water and air passenger transport. The relevant tourism activities related to passenger transportation are rail, road, water and air passenger transport.

The defined characteristic products of passenger transport understand the determining of the following segments of tourists and visitors: incoming tourists, incoming one-day visitors, domestic tourists, domestic oneday visitors, outgoing tourists in the segment of travelling within Croatia and outgoing one-day visitors in the segment of travelling within Croatia.
For each of the segments and the transportation characteristics of tourism products in compliance with the methodological frame of the tourism satellite account, the amount of tourism expenditures is estimated as the most significant segment of tourism consumption that includes not only what the visitors have paid from their own budget, but also the expenditures of the company / country related to the costs of business trips. Tourism expenditures do not include social transfers in goods, with the exception of refunding the expenditures that are initially realised by the visitor (e.g. healthcare services), as well as the expenditures related to the ownership of holiday houses.

The services of road passenger transport belong to the group of services characteristics for tourism. The estimation of the amount of tourism expenditures for the services of road passenger transport in the tourism satellite account (TSA: RMF 2008 and IRTS 2008 [21, 22]) is related to the status of tourists and visitors regarding the country of origin and the destination of travelling (domestic, outgoing, incoming) and the classification of products in compliance with IRTS 2008, i.e. the internationally adopted classification of products (Central Product Classification, CPC, Ver. 2.1) and production activities (International Standard Industrial Classification of All Economic Activities, ISIC, Rev. 4).

The group of road passenger transport services according to IRTS 2008 includes taxi services in urban and inter-city traffic, services of a rented car with a driver, services of urban ad suburban special bus transport (charter, excursions and other periodical services of bus transport), services of passenger transport using human or animal driving (e.g. rickshas and similar transport means), inter-city special bus transport (charter, excursions and other unscheduled bus services), other services such as transport by funiculars, cable cars, lifts, transport by buses and similar transport means for sightseeing (excluding rail), services of inter-city scheduled bus transport and services of inter-city special bus transport (charter, excursions and other periodical bus services).

The surface passenger transport services in compliance with the Classification of Products per Activities of the Republic of Croatia 2015 - KPD 2015 (OG 157/2014) include services of inter-city scheduled road transport of passengers, services of inter-city road passenger transport by special lines, other road passenger transport services by special lines, services of passenger transport by funiculars, cable cars and lifts, services of renting buses with drivers, services of road passenger transport for sightseeing and services of local special or charter bus transport.

\section{ROAD PASSENGER TRANSPORTATION ROAD PASSENGER TRANSPORT AND TOURISM IN CROATIA}

Traffic and tourism, as strategic economic activities of the Republic of Croatia, feature the characteristics of complex and dynamic systems [25], mutually conditioned by the guidelines of the supply and demand of the chain of values of tourism products.

Transport enables a circular flow of visitors from the place of residence to the destination and back, but it also ensures tourist mobility in the destination of stay. In some 
cases, transport also becomes a tourism attraction and a motive to undertake travelling $[26,28]$.

Public road transport encompasses the road transport of passengers or cargo which is under the same conditions available to all users of transport services and which is performed for commercial purposes in order to realize profit by carriers [30], and there is distinction between the national transport of passengers and international transport of passengers. National transport includes the transport of passengers from the place of entry to the place of exit within the borders of the Republic of Croatia, whereas international transport includes the transport of passengers between the place of entry into the Republic of Croatia and the place of exit abroad and vice versa, and the transport performed between two places abroad.

Table 2 Capacities of public passenger transport service providers in the period from 2010 to 2017 (Source: Central Bureau of Statistics of the Republic of Croatia)

\begin{tabular}{|r|c|c|c|c|c|c|c|c|}
\hline & 2010 & 2011 & 2012 & 2013 & 2014 & 2015 & 2016 & 2017 \\
\hline Coaches / Buses - total & 2,049 & 2,065 & 2,114 & 2,118 & 2,277 & 2,512 & 2,501 & 2,594 \\
\hline Seats & 97,113 & 93,841 & 95,250 & 98,135 & 103,692 & 114,390 & 113,852 & 119,213 \\
\hline Average number of seats & 47.4 & 45.4 & 45.1 & 46.3 & 45.5 & 45.5 & 45.5 & 46.0 \\
\hline Number of passenger places (seating and standing) & 110,002 & 105,651 & 106,103 & 109,128 & 115,625 & 129,221 & 128,217 & 135,869 \\
\hline
\end{tabular}

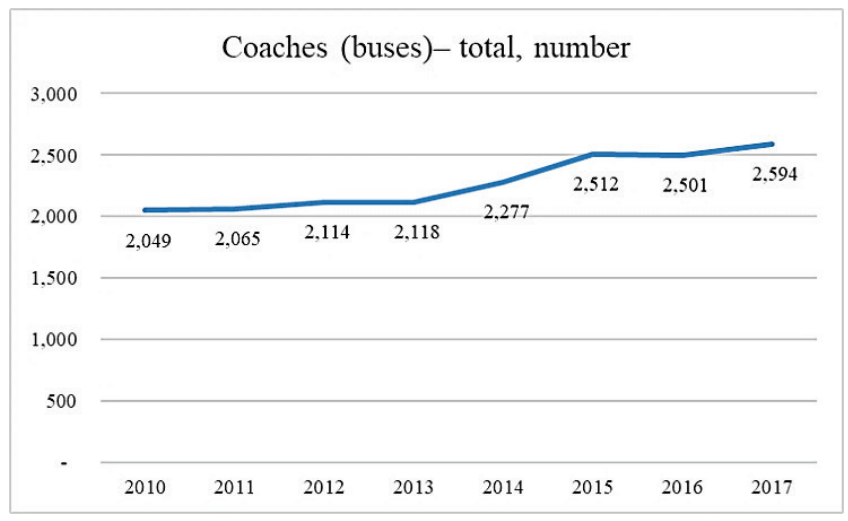

Average number of seats

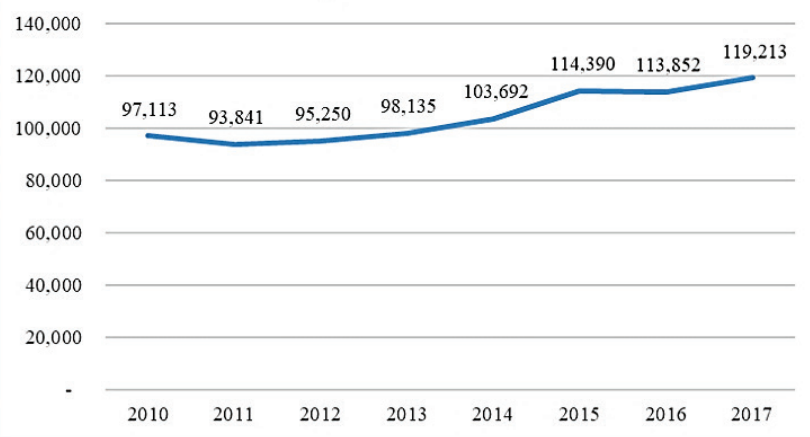

Figure 3 Capacities of public transport service providers in the period from 2010 to 2017 (Source: processed by the authors based on the data of the Central Bureau of
Statistics)

Table 3 Travelled kilometres and carried passengers in road passenger transport in the period from 2010 to 2017 (Source: Central Bureau of Statistics of the Republic of

\begin{tabular}{|c|c|c|c|c|c|c|c|c|}
\hline & 2010 & 2011 & 2012 & 2013 & 2014 & 2015 & 2016 & 2017 \\
\hline Travelled $\mathrm{km}$ of buses, in millions & 145.0 & 145.5 & 144.7 & 155.9 & 157.4 & 161.4 & 175.8 & 191.3 \\
\hline Travelled $\mathrm{km}$ of buses with passengers, in millions & 138.3 & 137.6 & 136.9 & 147.0 & 150.1 & 153.1 & 166.2 & 183.1 \\
\hline Carried passengers, in millions & 56.4 & 52.6 & 52.3 & 54.3 & 54.0 & 52.1 & 50.4 & 49.6 \\
\hline National transport & 53.9 & 50.5 & 49.9 & 52.1 & 52.4 & 51.2 & 49.2 & 47.9 \\
\hline International transport & 2.5 & 2.1 & 2.3 & 2.2 & 1.6 & 0.9 & 1.2 & 1.7 \\
\hline Passenger km, in millions & 3,284 & 3,145 & 3,249 & 3,507 & 3,648 & 3,377 & 3,802 & 4,150 \\
\hline National transport & 2,748 & 2,645 & 2,730 & 3,002 & 3,163 & 2,999 & 3,326 & 3,624 \\
\hline International transport & 536 & 500 & 519 & 505 & 485 & 378 & 476 & 526 \\
\hline
\end{tabular}

Regarding the character of the available data of official statistics and other available administrative sources, as well as the characteristics of the studies carried out as part of the TSA project, the focus of the analysis of road passenger

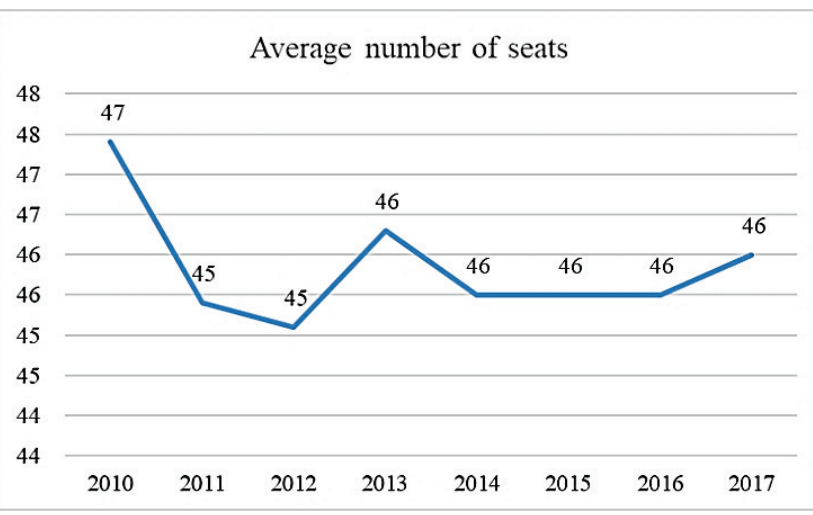

Number of passenger seats (seating and standing)

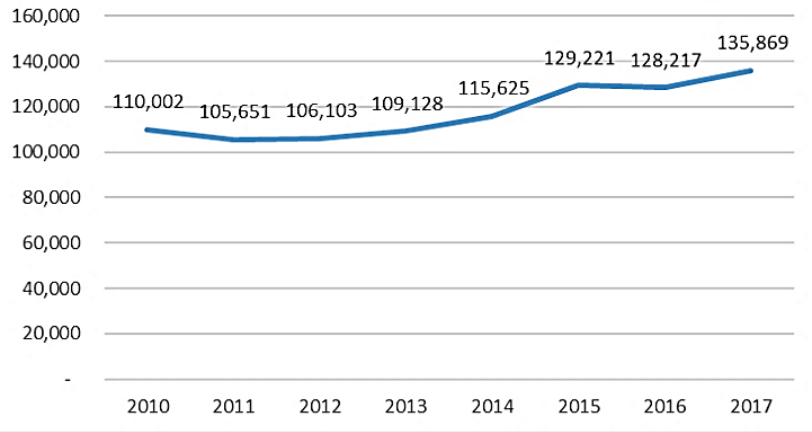
Statistics)

transport is related to the services of the inter-city scheduled road passenger transport.

The economic subjects that provided services of road passenger transport in 2017 disposed with 2,594 buses of the total capacity of 135,869 seating and standing passenger 
places, i.e. 119,213 seats (data of the Central Bureau of Statistics, Republic of Croatia). The tabular presentation of capacities in the period from 2010 to 2017 is given in Tab. 2, and the graphic presentation is given in Fig. 3.

\begin{tabular}{|c|c|c|c|c|c|c|c|}
\hline \multicolumn{8}{|c|}{ Republic of Croatia) } \\
\hline & 2011 & 2012 & 2013 & 2014 & 2015 & 2016 & 2017 \\
\hline & \multicolumn{7}{|c|}{ Change rates, percentages $(\%)$} \\
\hline Travelled km of buses & 0.34 & -0.55 & 7.74 & 0.96 & 2.54 & 8.92 & 8.82 \\
\hline Travelled km of buses with passengers & -0.51 & -0.51 & 7.38 & 2.11 & 2.00 & 8.56 & 10.17 \\
\hline Carried passengers & -6.74 & -0.57 & 3.82 & -0.55 & -3.52 & -3.26 & -1.59 \\
\hline National transport & -6.31 & -1.19 & 4.41 & 0.58 & -2.29 & -3.91 & -2.64 \\
\hline International transport & -16.00 & 9.52 & -4.35 & -27.27 & -43.75 & 33.33 & 41.67 \\
\hline Passenger km & -4.23 & 3.31 & 7.94 & 4.02 & -7.43 & 12.59 & 9.15 \\
\hline National transport & -3.75 & 3.21 & 9.96 & 5.36 & -5.18 & 10.90 & 8.96 \\
\hline International transport & -6.72 & 3.80 & -2.70 & -3.96 & -22.06 & 25.93 & 10.50 \\
\hline
\end{tabular}

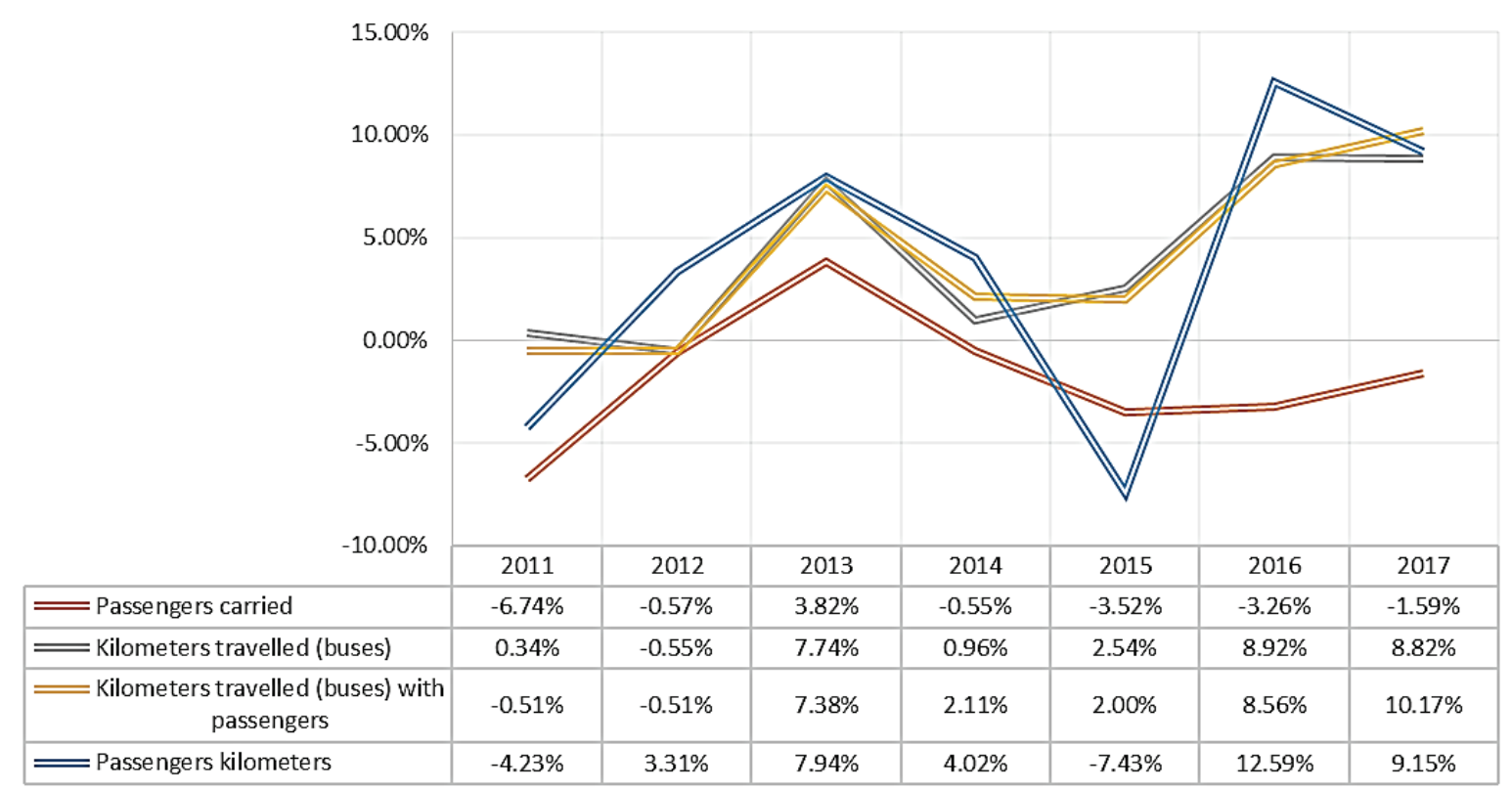

Figure 4 Change rates in the number of travelled kilometres and carried passengers in the road transport of passengers in the period from 2010 to 2017

During 2017, there were 49.6 million passengers carried in road passenger transport, out of which 96.6 percent in national and 3.4 in international transport. The trends indicate an increase in the number of travelled kilometres by buses with passengers.

The number of carried passengers in national transport is in a decrease and the number of carried passengers in international transport is increasing. Trends for the period from 2010 to 2017 in a numerical form are presented in Tables 3 and 4, whereas in a graphical form, they are presented in Fig. 4.

According to the Register of Annual Financial Reports managed by FINA (Croatian Financial Agency in charge of payment operations) in 2016, 433 registered business subjects in the activity Other passenger land transport n.e.c., which includes the urban and suburban surface transport of passengers, taxi service and other surface transport of passengers (excluding rail transport of passengers) realized a sales revenue (outside the group) in the amount of 1.8 billion kuna ( 82 percent of business revenues), i.e. a pre-tax profit in the amount of 97.6 million kuna. The average business revenue per business subject amounted to 5.1 million kuna (Tab. 5).
Table 5 Revenues and expenditures of the activity Other passenger land transport n.e.c. (NKD 2007 4939), in kn. Source: FINA (Croatian Financial Agency)

\begin{tabular}{|l|c|c|}
\multicolumn{1}{|c|}{ n.e.c. (NKD 2007 4939), in kn. Source: FINA (Croatian Financial Agency) } \\
\hline Business revenues & 2015 & 2016 \\
\hline Sales revenues (outside the group) & $2,057,596,568$ & $2,207,150,614$ \\
\hline Other business revenues & $1,697,000,487$ & $1,818,743,533$ \\
\hline Total revenues & $2,07,596,081$ & $388,407,081$ \\
\hline Total expenditures & $2,029,805,762$ & $2,227,713,445$ \\
\hline Pre-tax profit & $47,705,324$ & $2,130,041,765$ \\
\hline
\end{tabular}

\section{STUDY OF THE CHARACTERISTICS OF PASSENGERS AND TOURISTS IN CROATIA}

This chapter presents a methodotological framework for exploring the problem of road passenger transport. Moreover, it also presents the results of the research, based on the available databases, and the authors research.

\subsection{Methodological Frame of Research}

Regarding the nature of the available data of official statistics and other available administrative sources, as well as the features of the research carried out as part of this project, the focus of the analysis of road passenger transport 
is related to the services of the inter-city scheduled road transport of passengers. During the research, the following available sources of data have been used (Fig. 5):

- data of the Central Bureau of Statistics (Državni zavod za statistiku - DZS) about the number of carried passengers in the national and international road transport in 2016;

- data of the Financial Agency (Financijska agencija FINA) about the realized revenue of the company providers registered for inter-city transport in 2016 ;

- in-depth interview/survey of the representatives of service providers of inter-city road passenger transport, including also the collection of data about the physical and financial aspects of business in 2016;

- survey of passengers in inter-city bus transport, and

- the available data on aggregate expenditures for transport costs (number of visitors and average expenses) paid to Croatian transport service providers from the research Consumption of Foreign Passengers in Croatia and the Domestic Passengers Abroad from 2016, Tourist Activity of the Population of the Republic of Croatia 2016, TOMAS Summer 2017 [24].

The survey of passengers in inter-city bus transport was carried out in cooperation with a specialized agency for data gathering, and the research included 333 respondents, passengers in bus transport older than 18 years of age and 140 bus lines. The survey was carried out at seven bus stations during the period from July to November 2017 in order to ensure time- and location-diverse samples of passengers. There were 85 passengers surveyed at the bus station in Zagreb, 69 passengers in Split, 54 passengers in Osijek, 51 passengers in Rijeka, 33 passengers in Dubrovnik, 21 passengers in Varaždin, and 20 passengers in Poreč. During July and August, 147 interviews were carried out, and from September to November, 186 interviews were carried out. The method of collecting data was the computer-assisted personal interview (CAPI) method, and the instrument of gathering data was a structured questionnaire in the Croatian, English, and German languages. The computer-logic control of the input data in a questionnaire which includes the control of the allowed values of every question and the logic control between the questions in the questionnaire was performed in the SAS ${ }^{\circledR}$ System (Statistical Analitical Software) program package, and the data were analysed according to the main segments: domestic passengers on a one-day trip $(n=97)$, domestic passengers on multiple-day trip $(n=115)$, foreign passengers on a one-day trip $(n=16)$ and foreign passengers on multiple-day trip $(n=105)$.

Since the available sources on the amount and structure of tourism expenditures of domestic and foreign tourists and one-day visitors do not enable an estimate of the amount of tourism expenditures for the services of road passenger transport, the estimate has been done on the basis of a combination of indicators from the statistical and administrative sources on the side of supply, and the specific ad-hoc studies carried out on a sample of inter-city road transportation service providers, i.e. sample of passengers on these lines.
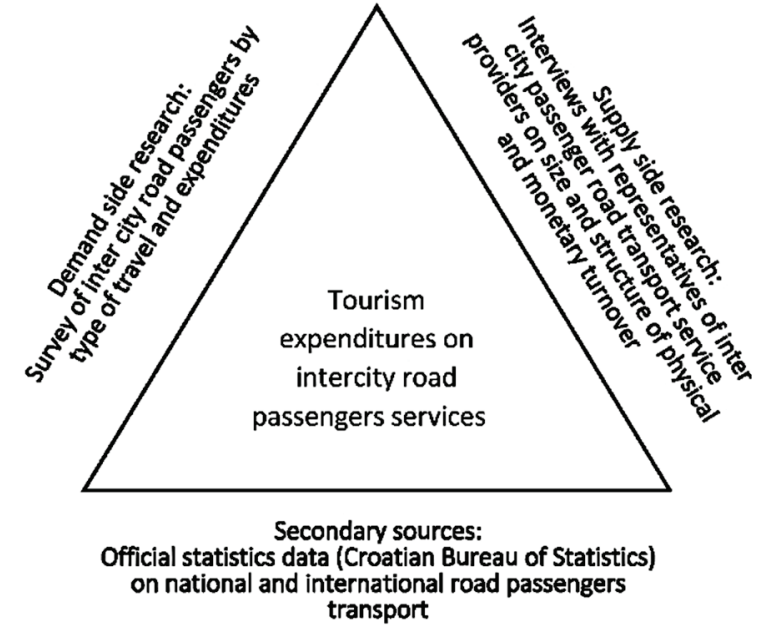

Figure 5 Model of algorithm for exploring the road transport demand of tourists

\subsection{Research Results}

In road inter-city passenger transport during 2016, there were 50.4 million of passengers carried. The number of carried passengers marks mild seasonal oscillations, with the summer period (July - September) marking the lowest level of demand, and the period from January to March marking the highest number of passengers. By providing road transport services in 2016, there were 1.8 billion kuna of revenues realized (business revenues - revenues from the sales outside the group) according to the data from the Register of Annual Financial Reports managed by FINA for 433 business subjects registered in the activity of Other Surface Transport of Passengers. It should be noted that the legal entities according to the data from the Central Bureau of Statistics carried 96.4 percent of the total number of passengers, and physical entities 3.6 percent. In national transport, passengers in road transport on average travel 67.6 $\mathrm{km}$, around 50 percent more than the distance of $40-50 \mathrm{~km}$ that can be considered a usual environment as a criterion for non-tourism travelling.

The realisation of in-depth interviews with the representatives of road transport service providers did not result in a satisfactory level of data quality that would provide insight into the structure of the gross values of production per segments of passengers and visitors. There were namely only three out of the planned twenty service providers who agreed to participate in the research. However, an overview of key findings has been given for further work on the estimate of the value of expenditures made by tourists and one-day visitors for the services of passenger road transportation:

- business revenue mainly, i.e. in whole realised through road transport services;

- share of travelling longer than $50 \mathrm{~km}$ (trips that can be considered as travelling outside the usual environment) oscillate extremely among the carriers, in the range from $5 \%$ to $0 \%$ of the total number of passengers, i.e. $30-95 \%$ of revenues;

- structure of the ticket price distribution: $20 \%$ tax, $10 \%$ station services, $10 \%$ other fees, $60 \%$ transport services provided by the carrier; 
- tickets are sold through the following channels: station $60 \%, 20 \%$ in the buses, $20 \%$ on the Internet,

- prices of tickets are season-wise adapted depending on the demand;

- key intermediary costs and other costs of the carrier: fuel, tolls, incomes, depreciation, service, taxes, and

- as key problems, the following are recognized: possibility of getting a preferential status related to the costs of fuel purchase (reduced excise tax) and added-value tax, duration of line concessions.

An additional insight into the characteristics of passengers is given by the carried out survey of passengers on bus lines with an adaptation to weights related to the seasons (period July - September and the rest of the year) and locations (counties of intensive and less intensive tourist traffic), resulting in the passengers from Croatia accounting for 84 percent of all passengers in road transportation, while foreign passengers account for 16 percent. The group in which from the total number of passengers, the non-tourist segment has been isolated (passengers who travel on scheduled lines for business and similar reasons and shorter trips), the citizens of Croatia account for 79 percent, and the passengers from abroad for 21 percent of the total number of visitors (according to their presence, the passengers from Bosnia and Herzegovina, Germany, Austria and France are the dominant ones).

During the survey, domestic visitors realised 91 percent of travelling to destinations in Croatia (domestic travels), and 9 percent with destinations abroad (outgoing travels). In terms of travels to a destination in Croatia (domestic travels), 35 percent of the trips were one-day, and 65 percent were multiple-day travels. All surveyed domestic passengers on outgoing travels planned multiple-day travels.

Considering the yearly average increase in road passenger transport prices in 2017 by $0.2 \%$ [25] and the average expenditures for the transport per passenger of $€ 11.1$ in 2017 (passengers on one-day trips spend on average $€ 7.6$, and on multiple-day trips $€ 13.1$ ), the total expenditures of domestic visitors for road transport services in the year 2016 in Croatia were estimated to be in the amount of $€ 296.1$ million, and of foreign visitors in the amount of $€ 100.5$ million.

Table 6 Structure of bus passengers regarding the origin and duration of travelling and the estimate of tourism expenditures in 2016. (Source: processed by the authors based on the research results from the document Report 2: Report on the carried out ad hoc studies realized as part of the project Tourism Satellite Account of the Republic of Croatia

\begin{tabular}{l} 
for 2016: The development of the statistical base and estimate of the national tourism consumption, Section 3) \\
\cline { 2 - 12 }
\end{tabular}

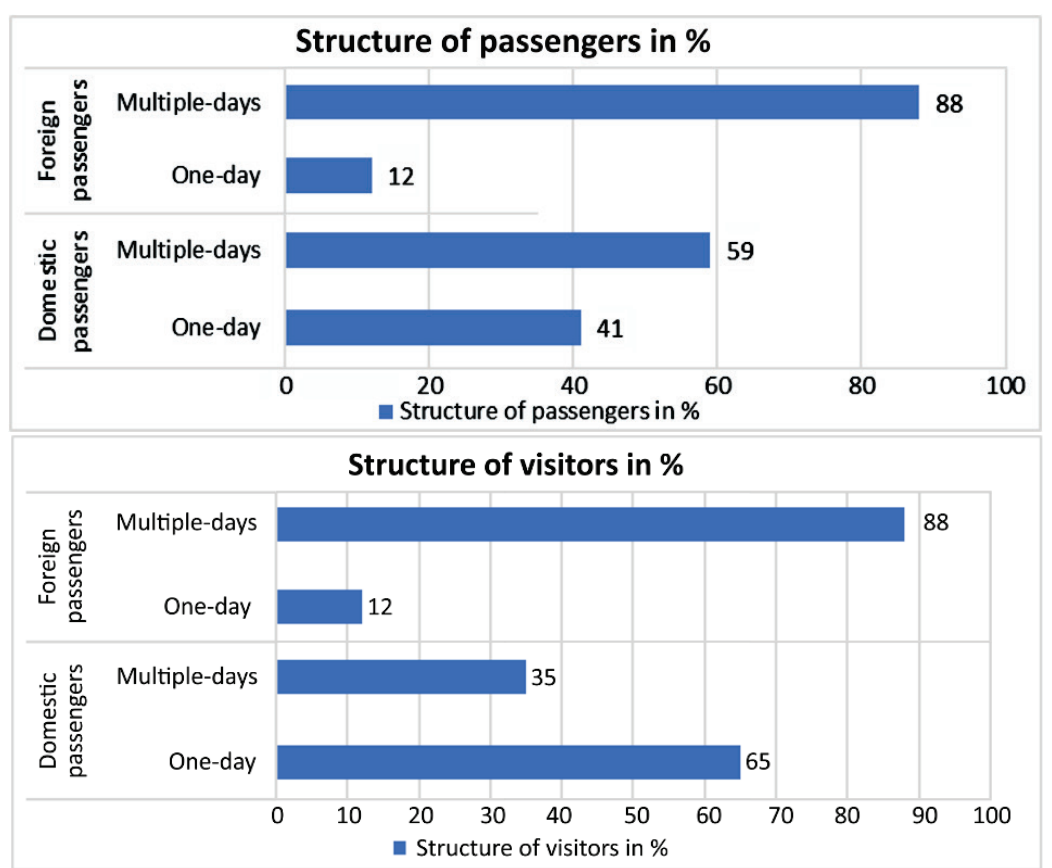

Figure 6 Structure of bus passengers according to the origin and duration of travelling, in percentages, year 2016 


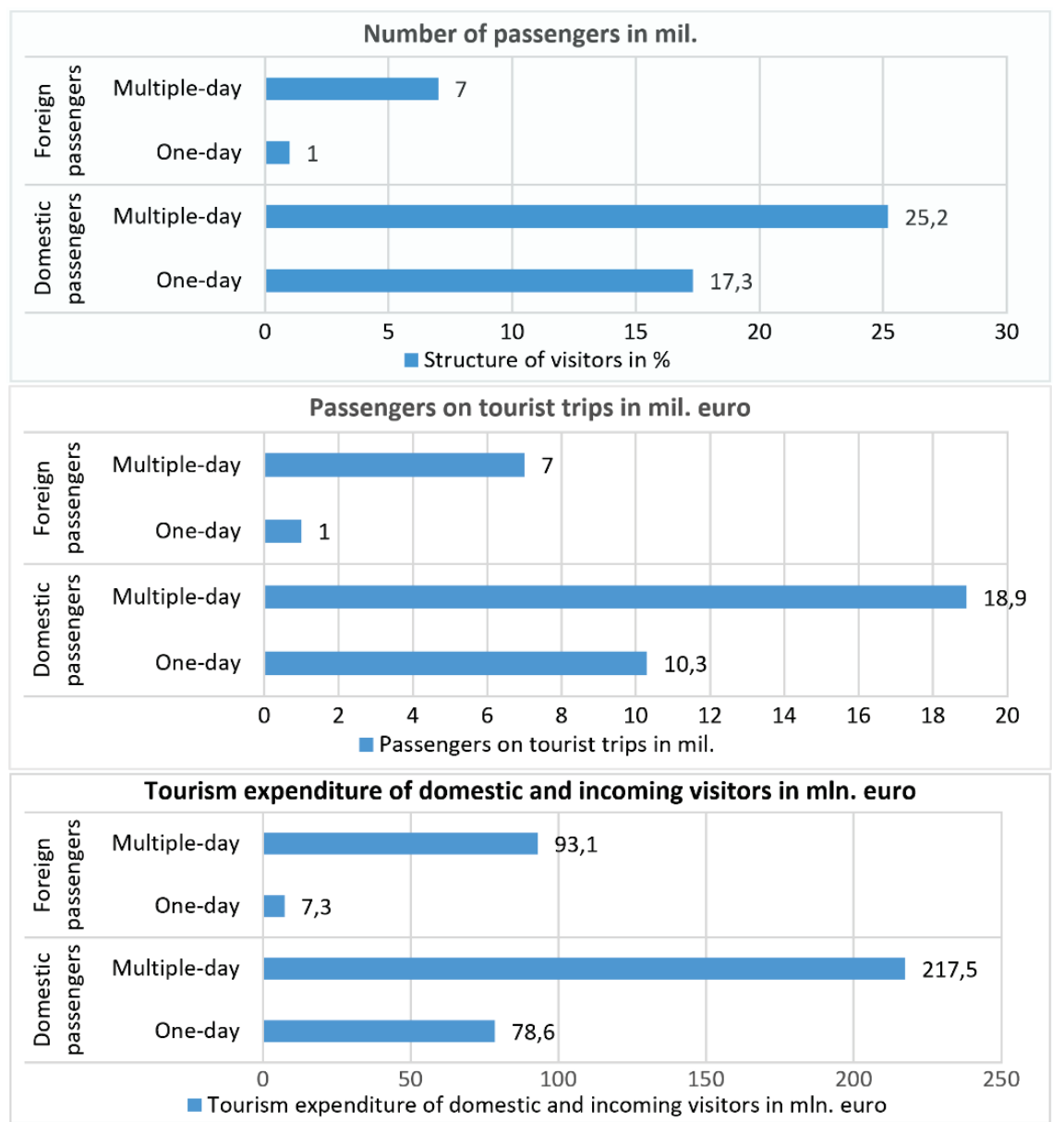

Figure 6 Structure of bus passengers according to the origin and duration of travelling, in percentages, year 2016 (continuataion)

\section{CONCLUSIONS}

The goal of the paper was to conduct an analysis of the volume and characteristics of tourism demand in public road passenger transportation in the Republic of Croatia, in order to determine the importance of tourism for this economic activity and to define the crucial physical and monetary characteristics of the overall demand of visitors. The paper presents the results of the research in tourism as one of the major factors of demand in public passenger transportation. Research was carried out for the needs of creating a Tourism Satellite Account for the Republic of Croatia for 2016. The Tourism Satellite Account provides insight into the macroeconomic aggregates that describe the volume and economic influence of tourism by considering the expenditures of visitors. Traffic and tourism, as strategic economic activities of the Republic of Croatia, feature the characteristics of complex and dynamic systems, mutually conditioned by the guidelines of the supply and demand of the value chain of tourism products.

The past research by other authors related to the transportation of tourists by road were mainly reduced to the studies of the travelling of tourists by passenger cars, i.e. individual road transport means. Moreover, few studies which indicate the use of the public road passenger transport of tourists in tourism destinations, i.e. tourism attractive areas, have been made. Therefore, this is the first more detailed research of the usage of public road transport by domestic and foreign tourists and visitors.

The methodology of research consisted of the analysis of the available data of the Central Bureau of Statistics about the Number of Carried Passengers in the National and International Road Transport in 2016, the analysis of the data of the Financial Agency about the realised revenue of the providers of companies registered for inter-city transport in 2016, of in-depth interviews and surveying of the representatives of the providers of services of inter-city road passenger transport, the gathering of data about the physical and financial aspects of operation in 2016, the survey of passengers in inter-city bus transport and the analysis of the available data on aggregate expenditures of the transport costs paid to the Croatian transport service providers from the research periodically carried out by the scientists and experts from the Institute for Tourism from Zagreb.

One should also mention the problems in studies, and those are the high prices for the services of surveying in order to obtain a sufficient sample which provides representative results and the non-cooperation of bus carriers to share business information about passenger transport.

The carried out studies have undoubtedly indicated the importance of the tourism demand of the road inter-city passenger transport in Croatia. Although the average length 
of travel is $67.6 \mathrm{~km}$, around 50 percent more than the distance of $40-50 \mathrm{~km}$, which can be considered the usual environment as a criterion for non-tourism travelling, the carried out survey of passengers has shown that during the surveying period, domestic visitors realized 91 percent of travelling to destinations in Croatia (domestic trips), and 9 percent to destinations abroad (outgoing travelling). In terms of travelling to destinations in Croatia (domestic travelling), 35 percent of travelling was a one-day trip, and 65 percent were multiple-day trips. All surveyed domestic passengers in outgoing travelling have planned a multiple-day trip.

It should be emphasised that the gathered data on the expenditures of passengers and visitors for road passenger transport services are only indicative of turism flows in public bus transportation and the carried out research should be considered as a pilot research which has indicated the problems of gathering data on the side of demand in road passenger transport. In this sense, future studies of road passenger transport need to be of a greater extent by volume and the structure should be adapted to the characteristics of the population. They should also ensure a more active participation of passenger transport service providers in order to enable the connection of data by supply and demand. Equally, future studies that should be carried out in order to obtain a complete picture about the usage of public transportation of tourists should focus on research in the transportation of passengers by air, water (sea and river) and rail transport.

\section{Acknowledgment}

The paper was written on the basis of research titled Tourism Satellite Account of the Republic of Croatia for 2016: Development of the statistical base and estimation of domestic tourism expenditure, Institute of Tourism, 2017, carried out for the needs of the Croatian Ministry of Tourism.

\section{REFERENCES}

[1] Pearce, P. L. \& Promnitz, J. (1984). Research for tourist Highways. Australian Road Research, 14(3), 156-160.

[2] Colon, I. (1985). The role of tourism in alcohol-related highway fatalities. Substance Use and Misuse, 20(4), 577-582. https://doi.org/10.3109/10826088509044936

[3] Van Middelkoop, M., Borgers, A. W. J., \& Timmermans, H. J. P. (2003). Modelling tourist destination choice using a decision table induction algorithm. Environment and Planning, 35(9), 1669 -1687. https://doi.org/10.1068/a35182

[4] Awaritefe , O. (2004). Motivation and Other Considerations in Tourist Destination Choice: A Case Study of Nigeria. Tourism Geographies, 6(3), 303-330. https://doi.org/10.1080/1461668042000249638

[5] Jurčević, M., Madunić, P., \& Tolušić, I. (2006). Relations Between Transport and Tourism - Croatia's Possibilities. PROMET, 18(5), 369-378. Available from: https://raffic.fpz.hr/index.php/PROMTT/article/view/708

[6] Aguiló, E., Palmer, T., \& Rosselló, J. (2012). Road transport for tourism: evaluating policy measures from consumer profiles. Road Transport for Tourism: Evaluating Policy
Measures from Consumer Profiles. Tourism Economics, 18(2), 281-293. https://doi.org/10.5367/te.2012.0120

[7] Novačko, L., Šimunović, Lj., \& Krasić, D. (2014). Estimation of Origin-Destination Trip Matrices for Small Cities. Promet, 26(5), 419-428. https://doi.org/10.7307/ptt.v26i5.1501

[8] Ševrović, M., Brčić, D., \& Kos, G. (2015). Transportation Costs and Subsidy Distribution Model for Urban and Suburban Public Passenger Transport. Promet, 27(1), 23-33. https://doi.org/10.7307/ptt.v27i1.1486

[9] Flausch, A. (2015). How public transport supports business and tourism in cities. Secretary general, International association of public transport (UITP).

[10] Kovačić, M. \& Milošević, T. (2016). Interdependence of Transport and Tourism. Pomorski zbornik, 52(1), 99-111. https://doi.org/10.18048/2016.52.06

[11] Glavni plan i strategija razvoja turizma Republike Hrvatske, Institut za turizam, Zagreb, 2011.

[12] Purba, A., Nakamura, F., Herianto, D., Wayan, D. I., Jafri, M., \& Niken, C. (2017). Transit system service quality in a tourism-education city and a business city. International Journal of Technology, 8(6), 1159-1167. https://doi.org/10.14716/ijtech.v8i6.768

[13] Hall, C. M., Le-Klähn, D.-T., \& Ram, Y. (2017). Tourism, Public Transport and Sustainable Mobility. Channel View Publications, Bristol/Blue Ridge Summit, p. 231.

[14] Hall, C. M., Le-Klähn, D.-T., \& Ram, Y. (2017). Tourism, public transport and sustainable mobility. Transport reviews. ChannelViewPublications, p. 248.

[15] Babic, T., Golob, M., \& Babic, S. (2018). The results of a study of a bus terminal for the purpose of tourism promotion. $7^{\text {th }}$ International scientific symposium economy of Eastern Croatia - vision and growth, Proceedings Paper, Osijek, 691-699.

[16] Castillo-Manzanoa, J. I., Castro-Nuñoa, M., López-Valpuestaa, L., Pedregal-Tercerob, D., J., \& Garrido-Michóc, J. H. (2018). High Speed Rail: Fast tracking tourism in the EU? Annals of Tourism Research, 71, 64-66. https://doi.org/10.1016/j.annals.2018.02.005

[17] Gronau, W. (2017). Encouraging behavioural change towards sustainable tourism: a German approach to free public transport for tourists, Journal of Sustainable Tourism, 25(2), 265-275. https://doi.org/10.1080/09669582.2016.1198357

[18] Gross, S. \& Bente, G. (2018). Sustainable mode of transport choices at the destination - public transport at German destinations. Tourism Review, 73(3), 401-420. https://doi.org/10.1108/TR-11-2017-0177

[19] Le-Klähn, D., Roosen, J., Gerike, R. C., \& Hall, C. M. (2015). Factors affecting tourists' public transport use and areas visited at destinations. Tourism Geographies, 17(5), 738-757. https://doi.org/10.1080/14616688.2015.1084527

[20] Ahlert, G. (2007). Methodological aspects of preparing the German TSA, empirical findings and initial reactions. Tourism Economics, 13(2), 275-287. https://doi.org/10.5367/000000007780823195

[21] International Recommendations for Tourism Statistics 2008, (IRTS 2008)

[22] Tourism Satellite Account: Recommended Methodological Framework 2008 (TSA: RMF 2008)

[23] Satelitski račun turizma RH za 2016. godinu: Razvoj statističke osnove i procjena unutarnje turističke potrošnje. Institut za turizam, Zagreb, 2017.

[24] Eurostat. European system of accounts, (ESA 2010), Luxembourg: Publications Office of the European Union, 2013. 
[25] Consumer Price Indices, december 2017. Croatian Burrau of Statistics, Zagreb, Januar 2018.

[26] Istraživanje javnog prijevoza putnika u cestovnom, željezničkom, zračnom i pomorskom prijevozu republike hrvatske za potrebe izrade satelitskog računa turizma (TSA), Fakultet prometnih znanosti, Zagreb, studeni 2017.

[27] Horak, S. (2006). Tranzitni turizam. Knjiga Hrvatski turizam bijelo, plavo, zeleno. Institut za turizam, Zagreb.

[28] TOMAS Ljeto 2017. Institut za turizam, 2018., Zagreb

[29] Horak S. Turizam i promet. Zagrebačka škola za menadžment, knjiga-edicija ZSM, Zagreb, 2007.

[30] Šolman, S̆. (2010). Uloga cestovnog prometa u turizmu Hrvatske. Acta Turistica Nova, 4(2), 121-250.

[31] Statistical Division United Nation: Handbook of Supply, Use and Input-Output Tables with Extensions and Applications, Studies in Methods, Series F, No. 74, Rev. 1, 2018.

\section{Authors' contacts:}

Goran Kos, PhD

(Corresponding author)

Institute for Tourism

Vrhovec 5, HR-10.000 Zagreb, Croatia

E-mail: goran.kos@iztzg.hr

Neven Ivandić, $\mathrm{PhD}$

Institute for Tourism

Vrhovec 5, HR-10.000 Zagreb, Croatia

E-mail: neven.ivandic@iztzg.hr

Krešimir Vidović, $\mathrm{PhD}$

Ericsson Nikola Tesla d.d.

Krapinska 45, HR-10.000 Zagreb, Croatia

E-mail: kresimir.vidovic@ericsson.hr 